\title{
EFEKTIFITAS JUS JERUK DAN JUS TOMAT TERHADAP HIPERTENSI DI DESA TAMBAKSOGRA BANYUMAS
}

\author{
Rani Marlina ${ }^{1}$, Ikhsan Mujahid ${ }^{2}$ \\ 1Fakultas Ilmu Kesehatan, 2Universitas Muhammadiyah Purwokerto, Jl. Letjen Soepardjo \\ Roestam PO. Box 229 Purwokerto 53181 \\ email: ranimarlina13@gmail.com \\ 2Fakultas Ilmu Kesehatan, 2Universitas Muhammadiyah Purwokerto, Jl. Letjen Soepardjo \\ Roestam PO. Box 229 Purwokerto 53181 \\ email: ikhsan_m83@yahoo.com
}

Submitted : 02-04-2020, Reviewer:06-04-2020, Accepted: 08-04-2020

\begin{abstract}
Background: Hypertension or an increase in blood pressure occurring in long term period, without early-stage detection and adequate medication may cause damages to kidney, heart, and brain. Objective: To analyse the effectiveness of orange and tomato juice on the blood pressure reduction of hypertension patients. Method: The research used quantitative method with quasy experiment of two group pre-test post-test designs. The sampling technique was purposive with 15 respondents of both juices. The independent statistical test was t-test. Result: The research result indicated that respondents' systolic blood pressure average before and after being given tomato juice were 155,603.54159 and 130.206.57050. Meanwhile, the average respondents diastolic blood pressure before and after administration of tomato juice was 97,262.15362 and 81.334.08248. Moreover, average respondents' systolic blood pressure before and after being given orange juice were 155,463.46135 and 137.264.09646. Meanwhile, the average respondents' diastolic blood pressure before and after administration of tomato juice was 97.861.24595 and 87.802.27408. Conclusion: There is a significant difference in systolic and diastolic blood pressure average of both groups on the change of hypertension patients' blood pressure, with the value of systolic t count of 3.820 and diastolic of 4.482 or $t$ count $t$ table and $p$ value of 0.05 . Tomato juice is more effective than orange juice in reducing blood pressure.
\end{abstract}

Keywords: orange juice, tomato juice, hypertension

ABSTRAK
Latar Belakang: Hipertensi atau Peningkatan tekanan darah yang berlangsung dalam
jangka waktu lama menimbulkan kerusakan pada ginjal, jantung, dan otak bila tidak
dideteksi secara dini dan mendapat pengobatan yang memadai. Tujuan: Menganalisa
efektifitas jus jeruk dan jus tomat terhadap penurunan tekanan darah pasien hipertensi
Metode: Penelitian ini menggunakan metode kuantitatif desain Quasy Eksperimen dengan
rancangan two group pre-test post-test design teknik purposive sample yaitu 15 responden
jus jeruk dan 15 jus tomat. Uji statistik Independent sampel t-test.Hasil: Hasil penelitian
rata-rata tekanan darah sistolik jus tomat sebelum 155,60 \pm 3.54159 dan setelah
$130.20 \pm 6.57050$. rata-rata tekanan diastolik sebelum diberikan jus tomat adalah
$97,26 \pm 2.15362$ dan setelah $81.33 \pm 4.08248$. Dan rata-rata tekanan sistolik sebelum
diberikan jus jeruk adalah $155,46 \pm 3.46135$ dan setelah $137.26 \pm 4.09646$. Tekanan
diastolik mean sebelum diberikan jus jeruk adalah $97.86 \pm 1.24595$ dan setelah
$87.80 \pm 2.27408$. Kesimpulan : Terdapat perbedaan signifikan rata-rata sistolik dan
diastolik kedua kelompok terhadap perubahan tekanan darah pasien hipertensi dengan 
nilai t hitung sistolik 3.820 dan diastolik 4.482 atau t hitung $>$ t table dan p-value $<0.05$. Jus tomat lebih efektif dibandingkan dengan jus jeruk untuk menurunkan tekanan darah

Kata Kunci : Jus Jeruk, Jus Tomat, Hipertensi

\section{PENDAHULUAN}

Hipertensi atau tekanan darah tinggi adalah peningkatan tekanan darah sistolik lebih dari $140 \mathrm{mmHg}$ dan tekanan darah diastolik lebih dari 90 mmHg pada dua kali pengukuran dengan selang waktu lima menit dalam keadaan cukup istirahat atau tenang. Peningkatan tekanan darah yang berlangsung dalam jangka waktu lama dapat menimbulkan kerusakan pada ginjal, jantung, dan otak bila tidak dideteksi secara dini dan mendapat pengobatan yang memadai.Sampai saat ini, hipertensi masih merupakan tantangan besar di Indonesia.Hipertensi merupakan kondisi yang sering ditemukan pada pelayanan kesehatan primer. (Depkes RI,2016).

Banyak faktor yang dapat menyebabkan terjadinya hipertensi. Departemen kesehatan (Depkes) tahun 2009 menunjukkan kejadian hipertensi dan penyakit kardiovaskular cenderung meningkat seiring dengan gaya hidup yang jauh dari perilaku hidup bersih dan sehat, mahalnya biaya pengobatan hipertensi, serta kurangnya sarana dan prasarana dalam penanggulangan hipertensi. Tingginya angka hipertensi juga dipengaruhi oleh kebiasaan merokok, kurangnya aktivitas, pola makan yang tidak sehat, obesitas dan stress (Yeni,dkk, 2010).

Penyakit hiperrtensi merupakan masalah kesehatan yang serius dikarenakan timbulnya sering kali tidak disadari jika memang ada maka sedikit gejala yang dirasakan, hipertensi dapat bertambah parah tanpa disadari hingga dapat mencapai tingkat mengancam hidup (Carlson, 2016).

Selain terapi farmakologis yang diberikan pada penderita hipertensi dapat juga diberikan terapi nonfarmakologis yang merupakan terapi nutrisi yang dilakukan dengan manajemen diet hipertensi.Contohnya dengan pembatasan konsumsi garam, mempertahankan asupan kalium, kalsium, dan magnesium serta membatasi asupan kalori jika berat badan meningkat. DASH (Dietary Approaches to Stop Hypertension) merekomendasikan pasien hipertensi banyak mengkonsumsi buah-buahan dan sayuran, meningkatkan konsumsi serat, dan minum banyak air. Terapi herbal merupakan terapi pilihan yang baik untuk penderita hipertensi Dendy,dkk, 2012).

Semakin banyakstudi epidemiologi secara konsisten menunjukkan efek perlindungan dari makanan yang kaya polifenol (buah, teh, anggur, kakao atau cokelat, dan buah jeruk khusus) terhadap beberapa faktor risiko menengah untuk CVD termasuk highdensity lipoprotein (LDL) kolesterol, tekanan darah tinggi, dan endotel penyelewengan fungsi.Jeruk (Citrus sinensis) jus juga dianggap sebagai sumber nutrisi penting yang baik seperti vitamin $\mathrm{C}$, folat, dan kalium.Vitamin $\mathrm{C}$ memiliki baru-baru ini ditemukan untuk melindungi sel-sel endotel dan LDL dari stres oksidatif intra dan ekstraselulerdan untuk mengurangi risiko aterosklerosis.Selain itu, asam folat dapat menurunkan homosistein plasmakonsentrasi dan untuk mengembalikan disfungsi 
endotel pada pasien dengan penyakit kardiovaskular.Kalium, di sisi lain, dapat berkontribusi menurunkan darah tekanan.Konsumsi jus jeruk empat minggu pada pria paruh baya sehat dan berat badan normal telah disarankan untuk mengurangi tekanan darah diastolik Diastolic Blood Pressure (DBP).Karena DBP adalah indikator perangkat resistensi pembuluh, jus jeruk dapat memiliki tertentu Keuntungan sehat. Konsumsi jus jeruk sinensis Citrus Sinensis Juice(CSJ) menjadi kebiasaan diet di seluruh dunia (Asgary, 2012).

Menurut Basith, 2013. Pengobatan non farmakologi yang dapat digunakan untuk mengobati hipertensi adalah jus tomat.Jus Tomat memiliki manfaat menurunkan tekanan darah karena tomat mengandung likopen. Terdapat 4,6 mg likopen dalam 100 gram tomat segar. Selain untuk masakan, tomat juga dikonsumsi mentah dalam bentuk jus. Penelitian yang dilakukan oleh Lestary (2012) menyebutkan bahwa konsumsi jus tomat yang berasal dari 150 gram tomat mampu menurunkan tekanan darah sistolik sebesar 11,76\% (kurang lebih 7,276 $\mathrm{mmHg}$ ) dan diastolik sebesar $8,82 \%$ (sebesar 3,321 $\mathrm{mmHg}$ ).

Hasil studi pendahuluan pada tanggal 14 oktober 2019 data per agustus 2019 Puskesmas Sumbang 1 Banyumas Desa tertinggi pertama di desa Banteran sebanyak 103 dan Desa tertinggi kedua Tambaksogra terdapat 102 orang. Desa tertinggi ketiga yaitu di desa Sumbang sebanyak 96 orang.

\section{METODE}

Desain penelitian yang digunakan dalam penelitian adalah menggunakan metode penelitian Quasi eksperimen yaitu kegiatan percobaan yang bertujuan untuk mengetahui suatu gejala atau pengaruh yang timbul sebagai suatu akibat dari adanya perilaku atau intervensi tertentu. Dengan rancangan two group pre-test post-test design yaitu rancangan penelitian dengan cara sebelum diberikan treatment/perlakuan variable diobservasi/diukur terlebih dahulu (pretest) setelah itu dilakukan treatment/perlakuan dan setelah treatment dilakukan pengukuran/observasi (posttest) (Aziz, 2017).Penelitian ini dilakukan bertujuan untuk mengetahui perbedaan efektifitas antara jus jeruk dengan jus tomat pada penderita hipertensi di Desa Tambaksogra Wilayah Puskesmas Sumbang 1 Banyumas.

\section{HASIL DAN PEMBAHASAN}

\section{Karakteristik responden} Tabel 4.1 Karakteristik Responden Berdasarkan Umur, Jenis Kelamin, Pendidikan, dan Pekerjaan

\begin{tabular}{|c|c|c|c|c|}
\hline \multirow[t]{3}{*}{ Fachistenstil: } & \multirow{2}{*}{\multicolumn{2}{|c|}{$\begin{array}{l}\text { Eeloweok fus } \\
\text { Ionse }\end{array}$}} & \multirow{2}{*}{\multicolumn{2}{|c|}{$\begin{array}{l}\text { Kelctuegik Jui } \\
\text { Jerak. }\end{array}$}} \\
\hline & & & & \\
\hline & $N$ & 36 & $\mathrm{~N}$ & 16 \\
\hline \multicolumn{5}{|l|}{ Jenia Kelanain } \\
\hline Lals- Daks & 2 & 13,3 & 3 & 20,0 \\
\hline Resermpuan & 13 & 86,7 & 12 & 25,0 \\
\hline \multicolumn{5}{|l|}{ Inta } \\
\hline 45-59 gatan & 15 & 300 & 19 & 100 \\
\hline \multicolumn{5}{|l|}{ Pekeringm } \\
\hline TRT & 12 & 50,0 & 12 & 80.0 \\
\hline Buruh & 3 & 20,0 & 1 & 6,7 \\
\hline Bravi & 0 & 5 & 2 & 13,3 \\
\hline \multicolumn{5}{|l|}{ Bendidion } \\
\hline gD & 14 & 93,3 & 12 & 15,0 \\
\hline SBA & 1 & 6.7 & 1 & 6,7 \\
\hline SMA & 0 & 0 & 2 & 13,3 \\
\hline Tetal & 15 & 100,0 & 15 & 100,0 \\
\hline
\end{tabular}

Berdasarkan tabel 4.1 menunjukkan bahwa karakteristik responden 
kelompok jus jeruk sebanyak 15 responden . Distribusi kelompok usia semua antara 45-59 tahun dengan jumlah responden 15 (100\%), jenis kelamin paling banyak perempuan 12 (80\%). Pekerjaan paling banyak adalah Ibu rumah tangga sebanyak 12 (80\%), tingkat pendidikan paling banyak adalah SD sebanyak 12 responden $(80 \%)$.

Berdasarkan tabel 4.1 menunjukkan bahwa karakteristik responden kelompok jus tomat sebanyak 15 responden. Distribusi kelompok usia semua antara 45-59 tahun dengan jumlah responden $15(100 \%)$, jenis kelamin paling banyak perempuan 13 responden $(86,7 \%)$. Pekerjaan paling banyak adalah Ibu rumah tangga dengan jumlah responden 13 responden $(86,7 \%)$, kemudian tingkat pendidikan paling banyak adalah SD dengan jumlah responden 14 (93,3\%).

Tabel 4.2 Distribusi frekuensi tekanan darah pasien hipertensi sebelum dan sesudah diberikan jus jeruk

\begin{tabular}{|c|c|c|c|c|c|c|}
\hline $\mathbb{T D}$ & & Pre & & & Post & \\
\hline & Mean & $\mathrm{SD}$ & $\mathrm{M}$ in-Max & Mean & SD & $\begin{array}{l}\text { Min- } \\
\text { Max }\end{array}$ \\
\hline Sistolik & 155.46 & 3,45135 & $\begin{array}{l}150.00- \\
160.00\end{array}$ & 137.26 & 4.09645 & $\begin{array}{l}130.00 \\
143.00\end{array}$ \\
\hline Diastolik & 97.86 & 1.24595 & $\begin{array}{l}95.00 \\
100.00\end{array}$ & 8780 & 2.27408 & $\begin{array}{l}8400- \\
9200\end{array}$ \\
\hline
\end{tabular}

Berdasarkan tabel 4.2 diatas dapat diketahui bahwa mean tekanan darah sistolik sebelum diberikan jus jeruk adalah 155,46 \pm 3.46135 dan setelah diberikan jus jeruk rata-ratanya menjadi 137.26 \pm 4.09646 . Sedangkan pada tekanan darah diastolik mean sebelum diberikan jus jeruk adalah $97.86 \pm 1.24595$ dan setelah diberikan jus jeruk rata-ratanya menjadi $87.80 \pm 2.27408$.
Tabel 4.3 Distribusi frekuensi tekanan darah pasien sebelum dan sesudah diberikan jus tomat

\begin{tabular}{lllllll}
\hline TD & \multicolumn{3}{c}{ Pre } & \multicolumn{3}{l}{ Post } \\
\hline & Mean & SD & Min-Max & Mean & SD & Mirn- \\
& & & & & & Max \\
Sistolik & 155,60 & 3.54159 & 149.00 & 130.20 & 6.57050 & $120.00-$ \\
& & & 160.00 & & & 140.00 \\
Diartolik & 97.26 & 2.15362 & $91.00-$ & 81.33 & 408248 & $70.00-$ \\
& & 99.00 & & & $88-00$ \\
\hline
\end{tabular}

Tabel 4.3 Berdasarkan tabel 4.3 diatas dapat diketahui bahwa mean tekanan darah sistolik sebelum diberikan jus tomat adalah $155,60 \pm 3.54159$ dan setelah diberikan jus tomat rata-ratanya menjadi 130.20 \pm 6.57050 . Sedangkan pada tekanan darah diastolik mean sebelum diberikan jus tomat adalah $97,26 \pm 2.15362$ dan setelah diberikan jus tomat rata-rataya menjadi $81.33 \pm 4.08248$.

Tabel 4.4 Perbedaan efektifitas antara jus tomat dan jus jeruk terhadap penurunan tekanan darah pada pasien hipertensi di desa Tambaksogra wilayah Puskesmas Sumbang 1 Banyumas

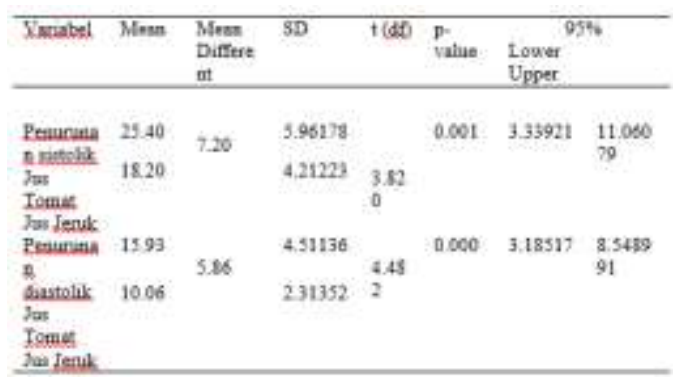

Berdasarkan tabel 4.4 tersebut diatas dapat diketahui bahwa rata-rata penurunan tekanan darah sistolik yang diberikan jus tomat sebesar 25,40, sedangkan kelompok yang dieberikan jus jeruk sebesar 18,20. Rata-rata penurunan tekanan darah diastolik yang 
diberikan jus tomat sebesar15,93, sedangkan kelompok yang diberikan jus jeruk sebesar 10,06. Adapun rerata penurunan tekanan darah sistolik kelompok jus tomat lebih besar 7,20x dan diastolik 5,86x dibandingkan dengan kelompok jus jeruk.

\section{Pembahasan}

\section{a. Karakteristik Responden}

Berdasarkan hasil penelitian diketahui bahwa rata-rata usia responden adalah 45-59 tahun, dengan usia tertua 59 tahun. Hasil penelitian ini sejalan dengan penelitian yang dilakukan oleh Syukraini Irza (2009) yang meneliti tentang Analisis faktor Resiko hipertensi pada Masyarakat Nagari Bungo Tanjung, Sumatra Barat. Dimana untuk usia lanjut memiliki resiko 4,76 kali lebih besar terkena hipertensi bila dibandingkan dengan usia 20-30 tahun. Hal ini sesuai dengan teori yang menyatakan bahwa hipertensi sering dijumpai pada orang usia 45 tahun atau lebih.

Bertambahnya usia menjadi permasalahan yang perlu perhatian khusus untuk lansia berkaitan dengan berlangsungnya proses menjadi tua, yang berakibat timbulnya perubahan fisik, kognitif, perasaan, sosial, dan seksual. (Azizah, 2011). Perubahan-perubahan pada lansia seperti hipertensi yang makin meningkat disebabkan oleh arteri akan kehilangan elastisitas atau kelenturan sehingga pembuluh darah akan berangsur-angsur menyempit dan menjadi kaku. Di negara negara maju yaitu perubahan pada system kardiovaskuler yang merupakan penyakit utama yang memakan korban karena akan berdampak pada penyakit lain seperti hipertensi, penyakit jantung koroner, jantung pulmonik, kardiomiopati, stroke, gagal ginjal. Berdasarkan hasil penelitian diketahui bahwa jumlah responden dengan jenis kelamin laki-laki adalah sebanyak 5 responden dan jumlah responden dengan jenis kelamin perempuan sebanyak 25 responden lebih banyak daripada jumlah responden laki-laki. Hasil penelitian ini sesuai dengan data Depkes (2013), bahwa prevalensi kasus kejadian hipertensi di Indonesia lebih banyak pada perempuan dibandingkan lakilaki dengan prevalensi sebesar $22,8 \%$ kasus pada laki-lakidan $28,8 \%$ pada perempuan dari keseluruhan total penderita hipertensi. Jenis kelamin sangat erat kaitannya terhadap terjadinya hipertensi dimana pada wanita lebih tinggi

ketika seorang wanita mengalami menopause, Anggraini (2012). Hal tersebut menunjukkan bahwa kejadian hipertensi pada perempuan dipengaruhi oleh kadar hormon estrogen. Hormon estrogen tersebut akan menurun kadarnya ketika perempuan memasuki usia tua (menopouse) sehingga perempuan menjadi lebih rentan terhadap hipertensi.

Hasil penelitian ini sejalan dengan penelitian yang dilakukan oleh (Rayhani 2013), mengenai hubungan jenis kelamin dengan kejadian 
hipertensi pada pasien yang berobat di Poliklinik Dewasa Puskesmas Bangkinang didapatkan hasil bahwa wanita lebih banyak menderita hipertensi dibandingkan dengan pria yaitu $51 \%$ banding $49 \%$. Berdasarkan hasil penelitian diketahui bahwa sebagian besar pekerjaan responden adalah Ibu Rumah Tangga sebanyak 24 responden. Hasil penelitian ini sejalan dengan penelitian yang dilakukan oleh Argina (2011), Kepatuhan Lansia Penderita Hipertensi dalam Pemenuhan Diet Hipertensi dimana jumlah responden paling banyak memiliki pekerjaan Ibu rumah tangga sebanyak 19 responden $(31,7 \%)$. Hasil penelitian ini didukung oleh teori yang dikemukakan oleh Harianto (2010) bahwa jenis pekerjaan berhubungan dengan aktifnya tubuh dalam melakukan aktivitas fisik/olahraga. Berdasarkan hasil penelitian diketahui bahwa sebagian besar tingkat pendidikan responden adalah sekolah dasar sebanyak 26 responden. Hasil penelitian ini sesuai dengan penelitian Wahyuni (2013) bahwa ada hubungan bermakna antara tingkat pendidikan dengan kejadian hipertensi, karena semakin tinggi pendidikan seseorang semakin mudah pula mereka menerima informasi, dan pada akhirnya makin banyak pula pengetahuan yang dimilikinya. Sebaliknya jika seseorang tingkat pendidikannya rendah, akan menghambat perkembangan sikap seseorang terhadap penerimaan, informasi dan nilai- nilai yang baru diperkenalkan (Mubarak, 2009). Hal tersebut juga sesuai dengan teori Notoatmodjo (2012) yang menyatakan bahwa pendidikan yang rendah akan mengahsilkan pengetahuan yang rendah pula.

b. Tekanan darah pasien hipertensi sebelum dan sesudah diberikan intervensi jus jeruk

Hasil penelitian menunjukkan perbedaan nilai tekanan darah pada penderita hipertensi di Desa Tambaksogra wilayah puskesmas Sumbang 1 Banyumas sebelum dan sesudah diberikan jus jeruk, dari penelitian ini diketahui bahwa jus jeruk efektif digunakan untuk menurunkan tekanan darah pada pasien hipertensi. Nilai rata-rata tekanan darah sistolik responden sebelum pemberian jus jeruk adalah sebesar $155,46 \mathrm{mmHg}$, sesudah diberikan jus jeruk nilainya mengalami penurunan menjadi $137,26 \mathrm{mmHg}$, sedangkan untuk tekanan diastolik sebelum diberikan jus jeruk adalah sebesar 97,86mmHg, kemudian setelah diberikan jus jeruk mengalami penurunan menjadi $87.80 \mathrm{mmHg}$. Menurut Asgary (2012), Semakin banyakstudi epidemiologi secara konsisten menunjukkan efek perlindungan dari makanan yang kaya polifenol (buah, teh, anggur, kakao atau cokelat, dan buah jeruk khusus) terhadap beberapa faktor risiko menengah untuk CVD termasuk high-density lipoprotein (LDL) kolesterol, tekanan darah tinggi, dan endotel penyelewengan fungsi.Jeruk (Citrus sinensis) jus juga 
dianggap sebagai sumber nutrisi penting yang baik seperti vitamin C, folat, dan kalium.Vitamin $\mathrm{C}$ memiliki baru-baru ini ditemukan untuk melindungi sel-sel endotel dan LDL dari stres oksidatif intra dan ekstraselulerdan untuk mengurangi risiko aterosklerosis. Selain itu, asam folat dapat menurunkan homosistein plasmakonsentrasi dan untuk mengembalikan disfungsi endotel pada pasien dengan penyakit kardiovaskular. Kalium, di sisi lain, dapat berkontribusi menurunkan darah tekanan. Konsumsi jus jeruk empat minggu pada pria paruh baya sehat dan berat badan normal telah disarankan untuk mengurangi tekanan darah diastolik Diastolic Blood Pressure (DBP). Karena DBP adalah indikator perangkat resistensi pembuluh, jus jeruk dapat memiliki tertentu keuntungan sehat. Konsumsi jus jeruk sinensis Citrus Sinensis Juice (CSJ) menjadi kebiasaan diet di seluruh dunia.

Menurut Daud 2010, penelitian yang berjudul efek antihipertensi jus buah jeruk Sunkist terhadap tekanan darah normal perempuan dewasa. Prospektif eksperimental sungguhan dengan rancangan acak lengkap (RAL) yang bersifat komparatif dengan desain penelitian prates dan postes. Data yang diukur adalah tekanan darah sistol dan diastol sebelum dan sesudah minum jus buah jeruk Sunkist dalam mmHg pada 30 orang perempuan dewasa.

$$
\begin{aligned}
& \text { Tekanan darah pasien } \\
& \text { hipertensi sebelum dan }
\end{aligned}
$$

\section{sesudah intervensi jus tomat}

Hasil penelitian menunjukkan perbedaan nilai tekanan darah pada penderita hipertensi di Desa Tambaksogra wilayah puskesmas Sumbang 1 Banyumas sebelum dan sesudah diberikan jus tomat, dari penelitian ini diketahui bahwa jus tomat efektif digunakan untuk menurunkan tekanan darah pada pasien hipertensi. Nilai rata-rata tekanan darah sistolik responden sebelum pemberian jus tomat adalah sebesar $155,60 \mathrm{mmHg}$, sesudah diberikan jus tomat nilainya mengalami penurunan menjadi $130,20 \mathrm{mmHg}$, sedangkan untuk tekanan diastolik sebelum diberikan jus tomat adalah sebesar 97,26mmHg, kemudian setelah diberikan jus tomat mengalami penurunan menjadi $81,33 \mathrm{mmHg}$. Menurut Basith (2013) pengobatan non farmakologi yang dapat digunakan untuk mengobati hipertensi adalah jus tomat. Jus Tomat memiliki manfaat menurunkan tekanan darah karena tomat mengandung likopen. Terdapat 4,6 $\mathrm{mg}$ likopen dalam 100 gram tomat segar. Selain untuk masakan, tomat juga dikonsumsi mentah dalam bentuk jus. Penelitian yang dilakukan oleh Lestary (2012) menyebutkan bahwa konsumsi jus tomat yang berasal dari 150 gram tomat mampu menurunkan tekanan darah sistolik sebesar $11,76 \%$ (kurang lebih 7,276 mmHg) dan 


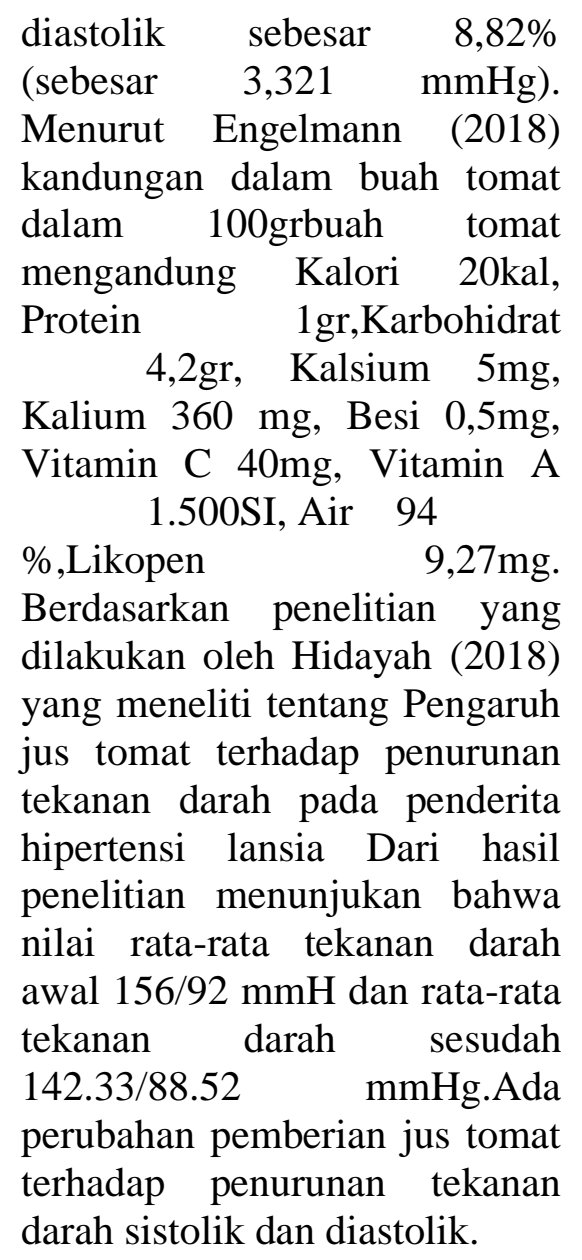

d. Perbedaan efektifitas antara jus jeruk dan jus tomat terhadap penurunan tekanan darah pasien hipertensi di Desa Tambaksogra wilayah Puskesmas Sumbang 1 Banyumas

Hasil penelitian ini menunjukkan bahwa terdapat perbedaan perubahan tekanan darah pada kelompok jus jeruk dan jus tomat. Berdasarkan tabel tersebut diatas dapat disimpulkan bahwa rata-rata penurunan tekanan darah sistolik kelompok yang diberikan jus jeruk adalah 18,20, dan tekanan darah diastolik adalah 10,06. Sedangkan rata-rata penurunan tekanan darah sistolik pada kelompok jus tomat adalah 25,40, dan tekanan diastoliknya 15,93 . Berdasarkan rata-rata penurunan tekanan darah sistolik ,kelompok yang diberikan jus tomat memiliki pengaruh yang lebih besar yaitu 7,20 (25,40$18,20)$ dan rata-rata perubahan tekanan darah diastolik pada kelompok jus tomat memiliki pengaruh yang lebih besar yaitu 5,87 (15,93-10,06). Adapun menurut Engelmann (2018) bahwa setiap 100gr buah tomat mengandung 360mg kalium dan menurut USDA (2016) bahwa setiap 100gr buah jeruk mengandung kalium $312 \mathrm{mg}$, maka dari hasil perhitungan statistik dan teori tersebut dapat disimpulkan bahwa jus tomat lebih efektif menurunkan tekanan darah daripada kelompok jus jeruk, sehingga dapat disimpulkan bahwa statistik ada perbedaan nilai perubahan tekanan darah tinggi yang diberikan jus jeruk dan jus tomat dengan nilai mean difference tekanan sistolik sebesar 7,20x dan tekanan diastolik sebesar 5,86x.

Berdasarkan penelitian yang dilakukan oleh Hidayah (2018) yang meneliti tentang Pengaruh jus tomat terhadap penurunan tekanan darah pada penderita hipertensi lansia Dari hasil penelitian menunjukan bahwa nilai rata-rata tekanan darah awal 156/92 $\mathrm{mmH}$ dan rata-rata tekanan darah sesudah 142.33/88.52 mmHg. Ada perubahan pemberian jus tomat terhadap penurunan tekanan darah sistolik dan diastolik. Sistolik sejumlah 5.33 - $1.00 \mathrm{mmHg}$ dan Diastolik sejumlah $1.64-0.33 \mathrm{mmHg}$.

Perbedaan tekanan darah sebelum dan sesudah mengkonsumsi jus tomat pada responden yang diuji dengan Paired $\mathrm{T}$ Test . Hasil menunjukkan terjadi penurunan tekanan darah pada penderita hipertensi dengan nilai $p$ 
value $=0,000<\mathrm{a}=0,05 . \quad$ Hal ini menunjukkan ada pengaruh yang signifikan jus tomat terhadap penurunan tekanan darah pada penderita hipertensi dengan nilai $\mathrm{p}=$ 0,000. Hasil penelitian ini sejalan dengan penelitian ini, besarnya penurunan tekanan darah selama pemberian jus tomat bervariasi, tergantung dari respon responden masing-masing. Penurunan tekanan darah karena adanya kandungan kalium dalam jus tomat dapat menurunkan tekanan darah dengan menghambat pelepasan renin sehingga terjadi peningkatan ekskresi natrium dan air (Nuziyati dkk, 2016).

Lita (2010) mengatakan bahwa kalium mempengaruhi system renin angiotensin dengan menghambat pengeluaran, renin yang bertugas mengubah angiotensinogen menjadi angiotensin I tetapi karena adanya blok pada system tersebut maka pembuluh darah mengalami vasodilatasi sehingga tekanan darah akan turun. Kalium juga menurunkan potensial membrane pada dinding pembuluh darah sehingga terjadi relaksasi pada dinding pembuluh darah dan akhirnya menurunkan tekanan darah. Dapat melancarkan keluarnya air seni sehingga menyebabkan anti hipertensi, hal ini sangat berhubungan dengan ACE sehingga angiotensin I tidak dapat diubah menjadi angiotensin II. Akibatnya jumlah angiotensin II berkurang dan menyebabkan vasokontriksi dan sekresi aldosterone untuk reabsorbsi natrium dan air secara otomatis akan menjadi berkurang sehingga tekanan darah akan menurun.

Wibowo (2010) menyatakan bahwa kalium merupakan elektrolit yang berfungsi sebagai pengatur cairan intra sel sehingga mencegah penumpukan cairan dan natrium dalam sel yang mampu meningkatkan tekanan darah. Kalium juga memiliki fungsi sebagai vasodilatasi pada pembuluh darah.Vasodilatasi pada pembuluh darah dapat menurunkan tahanan perifer dan meningkatkan curah jantung sehingga tekanan darah dapat normal.Selain itu, kalium dapat menghambat pelepasan rennin sehingga mengubah aktifitas sistem rennin angiotensin. Oleh sebab itu kalium yang tinggi merupakan komponen penting dalam proses penurunan tekanan darah.

\section{SIMPULAN}

1. Rata - rata usia responden adalah 45-59 tahun dengan usia termuda 45 tahun dan tertua 59 tahun. Jenis kelamin perempuan. Jenis pekerjaan yang paling banyak adalah Ibu rumah tangga. Tingkat pendidikan paling banyak adalah SD.

2. Tekanan darah sistolik dan diastolik pasien hipertensi sebelum diberikan jus jeruk rata-rata adalah $155,46 / 97,86 \mathrm{mmHg}$ dan sesudah diberikan jus jeruk rata-rata adalah $137,26 / 87,46 \mathrm{mmHg}$.

3. Tekanan darah sistolik dan diastolik pasien hipertensi sebelum diberika jus tomat rata-rata adalah $155,60 / 97,26 \mathrm{mmHg}$ dan sesudah diberikan jus tomat rata-rata adalah $130,20 / 81,33 \mathrm{mmHg}$.

4. Terdapat perbedaan rerata penurunan tekanan darah sistolik dan diastolik sebesar 18,20 \pm 4.21223 dan $10.06 \pm 2.31352$ pada kelompok jus jeruk, 25,40 \pm 5.96178 dan $15,93 \pm 4.51136$ pada kelompok jus 
tomat. Terdapat perbedaan yang signifikan antara jus jeruk dan jus tomat terhadap perubahan tekanan darah pasien hipertensi dengan selisih penurunan rata-rata tekanan darah jus tomat lebih tinggi. Sehingga jus tomat lebih efektif dibandingkan dengan jus jeruk untuk menurunkan tekanan darahpada pasien hipertensi di Desa Tambaksogra wilayah Puskesmas Sumbang 1 Banyumas.

\section{UCAPAN TERIMAKASIH}

1. Drs. Ikhsan Mujahid, M. Si., selaku pembimbing

2. Dr. Supriyadi , S.KM., M,KM selaku Penguji 1

3. Ns. Rakhmat Susilo , S.Kep., M.Kep selaku penguji 2

4. Seluruh Dosen dan staf Akademik Fakultas Ilmu Kesehatan Universitas Muhammadiyah Purwokerto

5. Kedua orang tua dan orang terkasih yang telah memberikan dukungan dan do'a.

\section{DAFTAR PUSTAKA}

Anggraini. (2012). Jenis Kelamin Penderita Hipertensi. Bandung: PT Remaja Rosida Karya.

Argina., Rini, S., Hairatama, R.(2011). Kepatuhan Lansia Penderita Hipertensi Dalam Pemenuhan Diet Hipertensi. Jurnal keperawatan PSIK Universitas Riau.6(1).

Asgary, S. Mahtab, K. (2012).Effects of citrus sinensis juice on blood pressure.US National Library of Medicine National Institutes of Health.https://www.ncbi.nl m.nih.gov/pmc/articles/PM C3653258/ (Diakses 10 november 2019).

Aziz, A.H.(2017). Metodelogi Penelitian Keperawatan dan Kesehatan. Jakarta: Salemba Medika.

Azizah, L.M. (2011). Keperawatan Lanjut Usia. Yogyakarta: Graha Ilmu.

Basith, A. (2013). Kitab Obat Hijau : Cara-cara Ilmiah Sehat Dengan Herbal.Solo: Tinta Medina.

Carlson, W. (2016).Mengatasi hipertensi. Bandung: Nuansa Cendikia.

Daud, P. R (2010). Efek Antihipertensi Jus Buah Jeruk Sunkist (Citrus Sinensis) (L.) Osbek) Terhadap Penurunan Tekanan Darah Normal Perempuan Dewasa. https://repository.maranath a.edu/2183/3/0610180_Cha pter1.pdf (diakses 29 januari 2020).

Dinkes Provinsi Jawa Tengah. (2018). Profil Kesehatan Provinsi Jawa Tengah tahun 2018, Dinas Kesehatan Jawa tengah,

Semarang.www.dinkesjaten gprov.go.id.

Dinkes Pemerintah Kabupaten Banyumas. (2018). Profil 
$\begin{array}{lr}\text { Kesehatan } & \text { Kabupaten } \\ \text { Banyumas } & \text { Tahun } \\ \text { 2018.http://dinkes.banyuma } \\ \text { skab.go.id/ }\end{array}$

Dendy K, Wan ND, Widia L.(2012). Efektivitas Konsumsi Jus Mentimun Terhadap Penurunan Tekanan Darah Pada Pasien Hipertensi. Ners Indonesia.2(2):124131

https://ejournal.unri.ac.id/in dex.php/JNI/article/view/20 $\underline{22}$ (diakses 11 september 2019).

Departemen Kesehatan Republik Indonesia.Pusat data dan informasi. Jakarta: Depkes RI; 2013.

Departemen Kesehatan Republik Indonesia.Pusat data dan informasi. Jakarta: Depkes RI; 2016.

Engelmann NJ, Clinton SK, Erdman-Jr JW.(2012). Nutritional Aspect of Phytoene and Phytofluene, Carotenoid Precussors to Lycopene. Adv Nutr.: 2(1): 51-61.

Harianto.(2010). Buku Ajar Kesehatan Kerja. Jakarta:EGC.

Hidayah.N, Utomo.A.Denys. (2018).Pengaruh Jus Tomat Terhadap Penurunan Tekanan Darah Pada Penderita Hipertensi Lansia.Prodi Keperawatan Lawang.Poltekkes

Kemenkes Malang.The Indonesian Journal of The Health Science https://www.researchgate.n et/publication/328309234(d iakses 17 september 2019).

Lita.(2010).Pengaruh Tomat Terhadap Penurunan Tekanan Darah.Skripsi. Universitas Kristen Maranatha. Diakses di http://repositorymaranatha. edu/2249/3/0710052_Chapt er1.PDF (diakses 30 Desember 2019).

Mubarok. (2009). Sosiologi Untuk Keperawatan Pengantar Dan Teori. Jakarta. Salemba Medika.

Nuziyati, SY. Fachlevy, A.F.(2016). Pengaruh Pemberian Jus Tomat (Lycopersicum commune) terhadap Penuru Tekanan Darah Sistolik dan Diastolik Penderita Hipertensi pada Lansia.

Notoatmodjo,S. (2010). Metodologi Penelitian Kesehatan. Jakarta: Rineka Cipta.

Notoatmodjo,S. (2012).Metodologi Penelitian Kesehatan Edisi Revisi. Jakarta: Rineka Cipta.

Rayhani. (2013). Hubungan Jenis Kelamin dengan Kejadian Hipertensi pada Pasien yang Berobat di Poliklinik Dewasa Puskesmas Bangkinang. Pekanbaru Riau: Faculty of Medicine University of Riau.

Syukraini, I. (2009).Analisis Faktor Resiko Hipertensi pada Masyarakat Nagari Bungo Tanjung, Sumatera Barat 
[internet].33-53, 60 Available from: http://repository.usu.ac.id/.

USDA Natonal Nutrient Database for Standard Reference.(2016). Full Report (All Nutrients) 09148, Raw Report.;.

Wahyuni. (2013). Hubungan Tingkat Pendidikan Dan Jenis Kelamin Dengan Kejadian Hipertensi Di Kelurahan Jagalan Di Wilayah Kerja Puskesmas Pucangsawit Surakarta. Jurnal Ilmu Keperawatan Indonesia. (1)1.

http://scholar.google.co.id/s cholar_url?url=http://jurnal. usahidsolo.ac.id/index.php/ JIKI/article/download/364/ $312 \& \mathrm{hl}=$ en\&sa $=$ X\&scisig $=$ AAGBfm2cOZ6NYH45qA 3ZL5eQw0Egkz6row\&nos

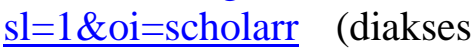
28 januari 2020).

Wibowo, M.A. 2010. Pengaruh Pemberian Jus Mentimun Terhadap Penurunan Tekanan Darah Sistolik dan Diastolik Penderita Hipertensi Esensial Pada Lansia Di PSTW Budi Luhur Yogyakarta. http://opac.unisayogya.ac.i d/1766/ (diakses 29 januari 2020).

Yeni Y, Djannah SN, Solikhah.(2009).

Faktor-faktor yang berhubungan dengan kejadian hipertensi pada wanita usia subur di puskesmas umbulharjo yogyakarta .Jurnal Kesmas
Universitas Ahmad Dahlan. 4(2): $76-143$ 